\title{
Genotypic profile of Listeria monocytogenes isolated in refrigerated chickens in southern Rio Grande do Sul, Brazil
}

\author{
Perfil genotípico de Listeria monocytogenes isolada em frangos \\ refrigerados comercializados na região sul do Rio Grande do Sul, Brasil
}

\author{
Karla Sequeira Mendonça ${ }^{\mathrm{I}, \text { II }}$ Geovana Brenner Michael ${ }^{\mathrm{III}}$ Élen Silveira Nalério ${ }^{\mathrm{IV}}$ \\ Marcelo MendonçaII Marisa Ribeiro Itapema Cardoso ${ }^{I I I}$ Wladimir Padilha da Silva ${ }^{I^{*}}$, II
}

ABSTRACT

Listeria monocytogenes is of notable concern to the food industry, due to its ubiquitous nature and ability to grow in adverse conditions. This study aimed to determine the genotypic profile of $\boldsymbol{L}$. monocytogenes strains isolated from refrigerated chickens marketed in the southern part of Rio Grande do Sul, Brazil. The strains of $\boldsymbol{L}$. monocytogenes isolated were characterized by serotyping and Pulsed Field Gel Electrophoresis (PFGE). Three different serotypes $(1 / 2 a, 1 / 2 b$ and $4 e)$ were evaluated by PFGE, and the macrorestriction patterns utilizing enzymes AscI and ApaI, revealed five different pulsotypes. The presence of such varied genotypic profiles demonstrates the prevalence of $\boldsymbol{L}$. monocytogenes contamination of chicken processing environments, which combined with ineffective cleaning procedures, allowing the survival, adaptation and proliferation of these pathogens, not only in the processing environment, but also in local grocery stores.

Key words: contamination, pathogen, prevalence, serotyping.

RESUMO

Listeria monocytogenes é uma notável preocupação para a indústria de alimentos, devido à sua natureza ubíqua e a capacidade de se multiplicar em condições adversas. Este estudo objetivou determinar o perfil genotípico de L. monocytogenes isolada a partir de frangos refrigerados comercializados na região sul do Rio Grande do Sul, Brasil. As cepas de L. monocytogenes foram selecionadas e caracterizadas por sorotipagem $e$ Eletroforese em Gel de Campo Pulsado (PFGE). Três sorotipos diferentes $(1 / 2 a, 1 / 2 b$ e 4 e) foram avaliados por PFGE, e a combinação dos padrões de macrorestrição utilizando as enzimas AscI e ApaI revelou cinco diferentes pulsotipos. A presença de diferentes perfis genotípicos demonstra a importância da contaminação no ambiente de processamento de frangos, o qual, juntamente com procedimentos de limpeza ineficazes, permitem a sobrevivência, adaptação e proliferação desses patógenos, não somente no ambiente de processamento, mas também no local de comercialização destes produtos.

Palavras-chave: contaminação, patógeno, prevalência, sorotipagem.

\section{INTRODUCTION}

The bacterium L. monocytogenes is a public health concern, causing listeriosis. Infection with $\boldsymbol{L}$. monocytogenes is potentially life threatening, producing a wide spectrum of disease states as enteritis, encephalitis, septicemia, meningitis or abortion (SCALLAN et al., 2011). The primary route of infection is through consumption of contaminated food, particularly, ready to eat products. Listeriosis has a high mortality rate, which occurs in welldefined risk groups, including immunocompromised individuals, elderly, children and pregnant women (FARBER \& PETERKIN, 1991).

Due to its ubiquitous nature, and ability to proliferate under refrigeration conditions, $\boldsymbol{L}$. monocytogenes has been isolated from a wide

\footnotetext{
'Laboratório de Microbiologia de Alimentos, Departamento de Ciência e Tecnologia Agroindustrial, Faculdade de Agronomia Eliseu Macie (FAEM), Universidade Federal de Pelotas (UFPel), Campus Universitário, 96010-900, Pelotas, RS, Brasil. E-mail: silvawp@ufpel.edu.br. *Corresponding author.

IIPrograma de Pós-graduação em Biotecnologia, Centro de Desenvolvimento Tecnológico, UFPel, Pelotas, RS, Brasil.

IIILaboratório de Medicina Veterinária Preventiva, Faculdade de Veterinária, Universidade Federal do Rio Grande do Sul (UFRGS), Porto Alegre, RS, Brasil.

${ }^{\text {IV }}$ Ciência da Carne, Embrapa Pecuária Sul, Bagé, RS, Brasil.
} 
variety of foods, particularly dairy and meat products (CARPENTIER \& CERF, 2011). In Brazil, there have not been any documented outbreaks of listeriosis associated with the consumption of contaminated food. However, L. monocytogenes has been successfully isolated from different food products (NALERIO et al., 2009; BUENO et al., 2010; GALVÃO et al., 2012).

In order to monitor the dissemination of $\boldsymbol{L}$. monocytogenes in food, several typification methods have been developed based on the size of DNA fragments generated by enzymatic digestion (LOMONACO et al., 2009). Among the molecular methods currently available, PFGE has proven to be effective and invaluable for epidemiological typing of $\boldsymbol{L}$. monocytogenes. This technique has assisted in tracking listeriosis outbreaks, as well as, determining the routes of food contamination (WIEDMANN, 2002). Moreover, PFGE is a sensitive technique, with good discriminatory power that generates highly reproducible data (GRAVES \& SWAMINATHAN, 2001).

The various stages involved in the production, processing/storage, and distribution/ commercialization of chickens, are all potential sources of contamination by $L$. monocytogenes (BARBALHO et al., 2005). Furthermore, it is important to investigate and understand the presence of L. monocytogenes in various food products, to establish appropriate strategies for its control. Therefore, the present study focused on determining the genotypic profile of samples obtained by PFGE. Listeria monocytogenes strains isolated and investigated in this study were obtained from raw refrigerated chickens marketed in Southern Rio Grande do Sul, Brazil.

\section{MATERIALS AND METHODS}

\section{Sampling and isolation}

A total of 45 samples of refrigerated chicken were evaluated. The samples were from two different brands of chicken, acquired in the original packaging, in supermarkets from the city of Pelotas, Brazil. Sampling was carried out according to the protocol established by RYSER \& DONNELLY (2001). To collect microbial samples from the surface of the chicken a superficial washing technique was employed. Each sample wash was performed in sterile plastic bags containing $225 \mathrm{~mL}$ of $0.1 \%$ peptone water. Aliquots of $25 \mathrm{~mL}$ of this liquid was inoculated into $225 \mathrm{~mL}$ of Listeria Enrichment Broth (LEB, Oxoid ${ }^{\circledR}$, Basingstoke, United Kingdom), enriched with the supplement SR141E (Oxoid), and incubated at $30^{\circ} \mathrm{C}$ for 24 hours.
Identification

The isolation of Listeria as well as its phenotypic and biochemical identification (at the species level) was carried out according to the protocol described by FARBER et al. (1994). Briefly, after the primary enrichment in LEB broth (Oxoid), a second enrichment was performed in Fraser Broth (Oxoid) and further inoculated in agars Oxford (Oxoid) and Palcam (Oxoid), in order to obtain typical Listeria colonies. Genus and species confirmation were performed through the motility test at $25^{\circ} \mathrm{C}$ (Motility Test Medium, Difco ${ }^{\circledR}$, Detroit, USA), catalase (3\% hydrogen peroxide), $\beta$-hemolysin (Horse Blood Agar 5\%) and sugar fermentation test with dextrose, rhamnose, xylose and mannitol (Vetec, Rio de Janeiro, Brazil). After, all isolates of $\boldsymbol{L}$. monocytogenes were grown in eppendorf tubes containing Tryptone Soy Agar (TSA, Acumedia ${ }^{\circledR}$, Baltimore, USA), enriched with $0.6 \%$ Yeast Extract (TSA-YE) incubated at 35$37^{\circ} \mathrm{C}$ for 24 hours, and stored for subsequent evaluation.

\section{Serotyping}

Strains of L. monocytogenes were characterized by serotyping by the Laboratório de Zoonoses Bacterianas, Departamento de Bacteriologia, Instituto Osvaldo Cruz (FIOCRUZ), Manguinhos, Rio de Janeiro (RJ).

\section{PFGE}

PFGE was performed following the PulseNet standardized protocol for subtyping of $\boldsymbol{L}$. monocytogenes (GRAVES \& SWAMINATHAN, 2001). Briefly, genomic DNA was prepared by mixing $240 \mu \mathrm{l}$ of a standardized cell suspension and $60 \mu \mathrm{l}$ of $10 \mathrm{mg} \cdot \mathrm{mL}^{-1}$ lysozyme solution (SigmaAldrich, St. Louis, USA), followed by incubation at $37^{\circ} \mathrm{C}$ for $10 \mathrm{~min}$. Subsequently, L. monocytogenes DNA cleavage was achieved by restriction with $A s c \mathrm{I}$ $\left(25 \mathrm{U} \mu \mathrm{L}^{-1}\right)$ and $A p a \mathrm{I}\left(160 \mathrm{U} \mu \mathrm{L}^{-1}\right)$ (New England BioLabs, Beverly, USA). Additionally, the restriction enzyme XbaI (Fermentas, Maryland, USA) was used for restriction of Salmonella enterica serotype Braenderup H9812 and functioned as the reference standard (HUNTER et al., 2005). Following restriction digestion, PFGE for L. monocytogenes and Salmonella was performed with the CHEF-DR II system (Bio-Rad Laboratories, Richmond, USA), in a $1 \%$ agarose gel and $0.5 \times \mathrm{TBE}$ buffer at $6 \mathrm{~V} \mathrm{~cm}-1$ for $23 \mathrm{~h}$ at $14^{\circ} \mathrm{C}$, with initial and final switch times of 4.0 and $40.0 \mathrm{~s}$, respectively. The gel was stained with ethidium bromide and the gel image was visualized with High Performance UV Transilluminator (UVP Inc., Upland, USA). The images were captured and digitized by Kodak 2200 system (Rochester, USA). 


\section{RESULTS AND DISCUSSION}

Of the 45 chicken samples analyzed, 15 (33.3\%) tested positive for $\boldsymbol{L}$. monocytogenes (Table 1). All of the samples evaluated were taken from the package in which they are usually sold, indicating that the contamination with this microorganism occurred at the processing plant. This is in agreement with other studies that demonstrated contamination of chicken by $\boldsymbol{L}$. monocytogenes while in processing plants. Consistent with this study, NALERIO et al. (2009) found that $11.7 \%$ of samples analyzed in a poultry slaughterhouse, were contaminated by this pathogen. Likewise, MIETTINEN et al. (2001) evaluated the presence of this bacterium in chicken from the Finnish local market, and found $62 \%$ of their chicken was contaminated by $\boldsymbol{L}$. monocytogenes. In Spain, VITAS et al. (2004), observed the presence of $\boldsymbol{L}$. monocytogenes in $36.1 \%$ of the samples, also showing high prevalence of the pathogen in the products from the market, reflecting the wide distribution of this bacterium within the poultry processing plants.

Following the phenotypic identification of $\boldsymbol{L}$. monocytogenes strains, the serotyping was performed. This technique consisted in a classical tool used to promote the differentiation of isolates based on the fact that different isolates of the same bacterial species, differ regarding the antigens presentation on the cell surface (WIEDMANN, 2002). In this study, six isolates used for genetic characterization have been characterized serologically, of which $33.3 \%$ (2) belonging to serotype $1 / 2 \mathrm{a} ; 33.3 \%$ (2) to serotype $1 / 2 \mathrm{~b}$, and $33.3 \%$ (2) to serotype $4 \mathrm{e}$. The single isolate belonging to serotype $1 / 2 \mathrm{c}$ was untyped, since it is different from the others. The serotypes distribution can be observed in table 1 .

There was a prevalence of serogroup $1 / 2$ $(66.6 \%)$, in agreement with the results obtained in

Table 1 - Isolation and serotyping of L. monocytogenes strains in refrigerated chickens marketed in Southern Rio Grande do Sul.

\begin{tabular}{llll}
\hline Source & Samples $^{*}$ & Isolates $^{*}$ & Serotypes \\
\hline & & & $4 \mathrm{e}(6)$ \\
Refrigerated & $33(\mathrm{~A})$ & $11(\mathrm{~A})$ & $1 / 2 \mathrm{a}(5)$ \\
chicken & $12(\mathrm{~B})$ & $4(\mathrm{~B})$ & $1 / 2 \mathrm{~b}(3)$ \\
& & & $1 / 2 \mathrm{c}(1)$ \\
Total & 45 & 15 & 15 \\
\hline
\end{tabular}

(A): Brand A; (B): Brand $\mathrm{B} ;{ }^{*}$ number of samples and isolates. other studies, which also showed that serotypes $1 / 2 \mathrm{a}$, $1 / 2 b, 1 / 2 c$, belonging to this serogroup are most frequently isolated from food and food processing environments (LEITE et al., 2006; TAMBURRO et al., 2010). LAWRENCE \& GILMOUR (1995), suggest that the recurring presence of isolates of serogroup $1 / 2$ in a wide variety of food and processing plants, may be related to surface antigens present in these isolates, potentially facilitating their ability to colonize equipment in the processing environment. Moreover, it is interesting to note that serotypes $1 / 2 \mathrm{a}$ and $1 / 2 \mathrm{~b}$, were found in the samples evaluated in this study. Serotypes $1 / 2 \mathrm{a}$ and $1 / 2 \mathrm{~b}$ are the most commonly associated serotypes observed with both individual cases and outbreaks of listeriosis worldwide, in addition to serotype 4b (ZHANG et al., 2013).

Although important, serotyping has low discriminatory power, particularly for $\boldsymbol{L}$. monocytogenes, as it has only 13 serotypes, limiting epidemiological application. Therefore, stronger molecular techniques are required. PFGE has been widely used for discrimination between serotypes of L. monocytogenes (THÉVENOT et al., 2006; VON LAER et al., 2009). Due to its sensitivity, high discriminatory power, standardization and reproducibility, PFGE is recognized as the most important typification technique for L. monocytogenes (WIEDMANN, 2002). The restriction enzymes commonly used are AscI and ApaI, when combined, allows accurate discrimination of this microorganism (GRAVES \& SWAMINATHAN, 2001; LÓPEZ et al., 2008). Additionally, the protocol recommended by PulseNet (Centers for Disease Control and Prevention - CDC), for typification of $\boldsymbol{L}$. monocytogenes, suggests the use of two enzymes, as the band patterns generated by these enzymes, are in the same size range, requiring only a single reference pattern (GRAVES \& SWAMINATHAN, 2001).

Among the fifteen strains of $\boldsymbol{L}$. monocytogenes obtained, six (isolates 5, 6, 9, 10, 23, 26) from three different serotypes, were selected for PFGE. With the exception of isolate 5, originating from final product of Brand $\mathrm{B}$, all the other were obtained from the Brand A products (Table 2). The PFGE genotyping of the strains with the enzymes AscI and ApaI, revealed five genotypic profiles for each enzyme individually, which assigned numbers and letters, respectively (Table 2).

The data obtained, allowed us to verify that the strain 5 , serotype $1 / 2 \mathrm{a}$, obtained from a product of the Brand B, showed pulsotype 9L. The strain 6 , also serotype 1/2a was obtained from a sample of Brand A, and composed the pulsotype 8J. Strain 23, serotype 
Table 2 - Genotypic and serologic profile of $L$. monocytogenes isolated in refrigerated chicken marketed in Southern Rio Grande do Sul.

\begin{tabular}{llccc}
\hline & & & \multicolumn{2}{c}{$\begin{array}{c}\text { Digestion profile by } \\
\text { endonuclease }\end{array}$} \\
Strains & Brand & Serotype & Ascl & Apal \\
\hline 5 & & & 9 & $\mathrm{~L}$ \\
6 & $\mathrm{~B}$ & $1 / 2 \mathrm{a}$ & 8 & $\mathrm{~J}$ \\
9 & $\mathrm{~A}$ & $1 / 2 \mathrm{a}$ & 7 & $\mathrm{H}$ \\
10 & $\mathrm{~A}$ & $4 \mathrm{e}$ & 7 & $\mathrm{H}$ \\
23 & $\mathrm{~A}$ & $4 \mathrm{e}$ & 14 & $\mathrm{P}$ \\
26 & $\mathrm{~A}$ & $1 / 2 \mathrm{~b}$ & 14 & $\mathrm{~N}$ \\
\hline
\end{tabular}

"Identification number.

$1 / 2 \mathrm{~b}$, a product of Brand A, showed pulsotype $14 \mathrm{M}$, while the strain 26 , also serotype $1 / 2 \mathrm{~b}$, with the same origin, had different genotypic profile, pulsotype $12 \mathrm{~N}$. Figure 1 demonstrates the different genotypic profiles obtained with the restriction of endonucleases $A s c \mathrm{I}$ and ApaI, for $\boldsymbol{L}$. monocytogenes strains from refrigerated chickens marketed in southern Rio Grande do Sul.

Strains 9 and 10, both serotype 4e showed the same genotypic profile, pulsotype $7 \mathrm{H}$ (Table 2). It is interesting to note that these strains were isolated from samples collected at different local grocery stores, on different days, although the samples have been obtained from refrigerated chickens that were processed in the same slaughterhouse (Brand A). The prevalence of $\boldsymbol{L}$. monocytogenes in refrigerated chickens from local grocery stores, along with the diversity of serotypes and the genotypic profiles found, reflect the wide distribution of this pathogen in poultry slaughterhouses, and the difficulty of their elimination from the environment of processing plants. Moreover, the inefficiency of the cleaning and sanitization procedures allow the adaptation and survival of $\boldsymbol{L}$. monocytogenes strains in food processing environments, resulting in persistence and contamination of the final product (MENDONÇA et al., 2012; LEONG et al., 2014).

\section{CONCLUSION}

There is presence of different groups of L. monocytogenes in refrigerated chickens from the local grocery stores of southern Rio Grande do Sul. Since the samples were acquired from the primary packaging, these results emphasize the importance of contamination during the food processing.

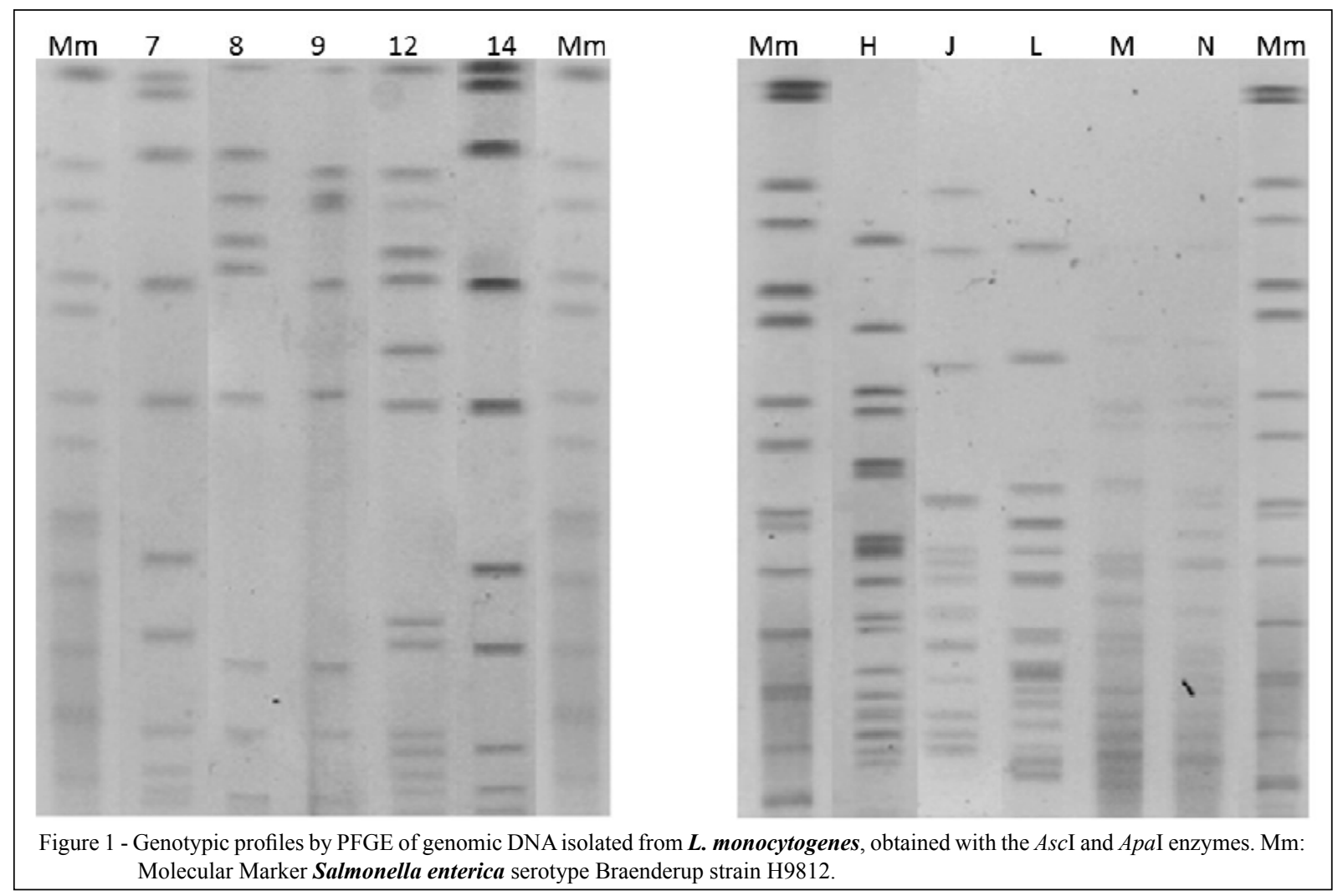

Ciência Rural, v.46, n.1, jan, 2016. 


\section{ACKNOWLEDGEMENTS}

The authors would like to thank Dr. Amy E. Fleishman Littlejohn from Northern Arizona University for the English Grammar assistance of the manuscript. Authors also thank Coordenadoria de Aperfeiçoamento de Pessoal de Nível Superior (CAPES) and Fundação de Amparo à Pesquisa do Estado do Rio Grande do Sul (FAPERGS) for the scholarships and Conselho Nacional de Desenvolvimento Científico e Tecnológico (CNPq) (grant 482524/2010-3) and FAPERGS (grant PQG 11/1271-9) for financial support.

\section{REFERENCES}

BARBALHO, T.C.F. et al. Prevalence of Listeria spp. at a poultry processing plant in Brazil and a phage test for a rapid test confirmation of suspect colonies. Food Control, v.16, n.3, p.211-216, 2005. Available from: <http://www.sciencedirect. com/science/article/pii/S0956713504000362>. Accessed: Jan. 12, 2014. doi:10.1016/j.foodcont.2004.01.014.

BUENO, V.F. et al. Characterization of Listeria monocytogenes isolates of food and human origins from Brazil using molecular typing procedures and in vitro cell culture assays. International Journal of Environmental Health Research, v.20, n.1, p.43-59, 2010. Available from: <http://www.ncbi. nlm.nih.gov/pubmed/20104385>. Accessed: Jul. 03, 2015. doi: $10.1080 / 09603120903281283$.

CARPENTIER, B.; CERF, O. Review-Persistence of Listeria monocytogenes in food industry equipment and premises. International Journal of Food Microbiology, n.145, p.18, 2011. Available from: <http://www.ncbi.nlm.nih.gov/ pubmed/21276634>. Accessed: Jul. 03, 2015. doi:10.1016/j. ijfoodmicro.2011.01.005.

FARBER, J.M.; PETERKIN, P.I. Listeria monocytogenes, a FoodBorne Pathogen. Microbiological Reviews, v.55, n.3, p.476-511, 1991. Available from: <http://mmbr.asm.org/content/55/3/476. long>. Accessed: Mar. 19, 2014.

FARBER, J.M. et al. Isolation of Listeria monocytogenes from all food and environmental samples. Government of Canada - HPB Method. Quebec (Canadá): Polyscience Publications, Sept. 1994. Available from: <http://aem.asm.org/content/72/7/5073.full >. Accessed: Mar. 03, 2014.

GALVÃO, N.N. et al. PFGE characterisation and adhesion ability of Listeria monocytogenes isolates obtained from bovine carcasses and beef processing facilities. Meat Science, v.92, n.4, p.635-643, 2012. Available from: <http://www.ncbi.nlm.nih.gov/ pubmed/22748307>. Accessed: Jan. 18, 2015. doi:10.1016/j. meatsci.2012.06.011.

GRAVES, L.; SWAMINATHAN, B. PulseNet standardized protocol for subtyping Listeria monocytogenes by macrorestriction and pulsed-field gel electrophoresis. International Journal of Food Microbiology, v.65, p.55-62, 2001. Available from: <http:// www.sciencedirect.com/science/article/pii/S0168160500005018>. Accessed: Mar. 19, 2014. doi: 10.1385/1-59259-990-7:057.

HUNTER, S.B. et al. Establishment of a universal size standard strain for use with the PulseNet standardized Pulsed-Field gel electrophoresis protocols: converting the national databases to the new size standard. Journal of Clinical Microbiology, v.43, n.3, p.1045-1050, 2005. Available from: <http://jcm.asm.org/ content/43/3/1045.long>. Accessed: Mar. 19, 2014. doi: 10.1128/ JCM.43.3.1045-1050.2005.

LAWRENCE, L.M.; GILMOUR, A. Characterization of Listeria monocytogenes isolated from poultry products and from poultryprocessing environmental by randon amplification of polymorphic DNA and multilocus enzyme electrophoresis. Applied and Environmental Microbiology, v.61, n.6, p.2139-2144, 1995. Available from: <http://www.ncbi.nlm.nih.gov/pmc/articles/ PMC167487/>. Accessed: Mar. 19, 2014.

LEITE, P. et al. Comparative characterization of Listeria monocytogenes isolated from Portuguese farmhouse ewe's cheese and from humans. International Journal of Food Microbiology, v.106, p.111-121, 2006. Available from: <http:// www.sciencedirect.com/science/article/pii/S0168160505004186>. Accessed: Mar. 19, 2014. doi: 10.1016/j.ijfoodmicro.2005.05.017.

LEONG, D. et al. Monitoring occurrence and persistence of Listeria monocytogenes in foods and food processing environments in the Republic of Ireland. Frontiers in Microbiology, v.5, a.436, p.1-8, 2014. Available from: <http://www.ncbi.nlm.nih.gov/ pubmed/25191314>. Accessed: Jan. 18, 2015. doi: 10.3389/ fmicb.2014.00436.

LOMONACO, S. et al. Listeria monocytogenes in Gorgonzola: subtypes, diversity and persistence over time. International Journal of Food Microbiology, v.128, p.516-520, 2009. Available from: $<$ http://www.sciencedirect.com/science/article/pii/ S0168160508005527>. Accessed: Mar. 19, 2014. doi: 10.1016/j. ijfoodmicro.2008.10.009.

LÓPEZ, V. et al. Molecular tracking of Listeria monocytogenes in an Iberian pig abattoir and processing plant. Meat Science, v.78, p.130-134, 2008. Available from: <http://www.ncbi.nlm.nih.gov/ pubmed/22062102>. Accessed: Mar. 07, 2015. doi: 10.1016/j. meatsci.2007.05.002

MENDONÇA, K.S. et al. Genetic relatedness among Listeria monocytogenes isolated in foods and food production chain in southern Rio Grande do Sul, Brazil. Food Control, n.28, p.171177, 2012. Available from: <http://www.sciencedirect.com/ science/article/pii/S0956713512001764>. Accessed: Mar. 19, 2014. doi:10.1016/j.foodcont.2012.04.014.

MIETTINEN, M.K. et al. Molecular epidemiology of an outbreak of febrile gastroenteritis caused by Listeria monocytogenes in cold-smoked rainbow trout. Journal of Clinical Microbiology, v.37, p.2358-2360, 2001. Available from: <http://jcm.asm.org/ content/37/7/2358.short>. Accessed: Sept. 25, 2014.

NALERIO, E.S. et al. Listeria monocytogenes: monitoramento desse perigo biológico na cadeia produtiva de frangos do sul do Rio Grande do Sul. Ciência e Tecnologia de Alimentos, v.3, p.626-630, 2009. Available from: <http://www.scielo.br/pdf/cta/ v29n3/a26v29n3.pdf>. Accessed: May 29, 2015. doi: 10.1590/ S0101-20612009000300026.

RYSER, E.T.; DONNELLY, C.W. Compendium of methods for the microbiological examination of foods. 4.ed. Washington: APHA, 2001. Chapt. 36, p.343-363.

TAMBURRO, M. et al. Typing of Listeria monocytogenes strains isolated in Italy by inlA gene characterization and evaluation of a new cost-effective approach to antisera selection for serotyping. 
Journal of Applied Microbiology, v.108, n.5, p.1602-1611, 2010 Available from: <http://www.ncbi.nlm.nih.gov/pubmed/19811568> Acessed: May 29, 2015. doi: 10.1111/j.1365-2672.2009.04555.x.

SCALLAN, E. et al. Foodborne illness acquired in the United States-unspecified agents. Emerging Infectious Diseases., v.17, n.1, p.16-22, 2011. Available from: <http://t.perishablepundit. com/docs/foodborneillness.pdf $>$. Accessed: May 29, 2015. doi: 10.3201/eid1701.P11101

THÉVENOT, D. et al. Serological and molecular ecology of Listeria monocytogenes isolates collected from 13 French pork meat salting-curing plants and their products. International Journal of Food Microbiology, v.112, p.153-161, 2006. Available from: $<$ http://www.sciencedirect.com/science/article/pii/ S016816050600332>. Accessed: Mar. 03, 2014. doi: 10.1016/j. ijfoodmicro.2006.06.017

VITAS, A.I. et al. Occurrence of Listeria monocytogenes in fresh and processed foods in Navarra (Spain). International Journal of Food Microbiology, v.90, n.3, p.349-356, 2004. Available from: $<$ http://www.sciencedirect.com/science/article/pii/
S0168160503003143>. Accessed: May 29, 2015. doi:10.1016/ S0168-1605(03)00314-3.

VON LAER, A.E. et al. Characterization of Listeria monocytogenes Isolated from a Fresh Mixed Sausage Processing Line in Pelotas-RS by PFGE. Brazilian Journal of Microbiology, v.40, p.574-582, 2009. Available from: <http://www.scielo. br/scielo.php?pid=S1517-83822009000300021\&script $=$ sci arttext $>$. Accessed: Mar. 19, 2014. doi: 10.1590/S151783822009000300021 .

WIEDMANN, M. Molecular subtyping methods for Listeria monocytogenes. Journal of AOAC International, v.85, n.2, 2002. Available from: <http:/www.ingentaconnect.com/content/aoac/ jaoac/2002/00000085/00000002/art00032> . Accessed: May, 29, 2015.

ZHANG, W. et al. Isolation and characterization of Listeria monocytogenes isolates from retail foods in Shaanxi Province, China. Foodborne Pathogens and Disease, v.10, n.10, p.867872, 2013. Available from: <http://www.ncbi.nlm.nih.gov/ pubmed/23841657>. Accessed: Feb. 28, 2015. doi: 10.1089/ fpd.2013.1528. 